\title{
Azolla planting reduces methane emission and nitrogen fertilizer application in double rice cropping system in southern China
}

\author{
Heshui Xu ${ }^{1}$ • Bo Zhu ${ }^{2}$ • Jingna Liu ${ }^{1,3}$ • Dengyun $\mathrm{Li}^{1} \cdot$ Yadong Yang $^{1} \cdot$ Kai Zhang ${ }^{1}$ • \\ Ying Jiang ${ }^{1} \cdot$ Yuegao Hu ${ }^{1} \cdot$ Zhaohai Zeng $^{1}$
}

Accepted: 28 June 2017 /Published online: 20 July 2017

(C) INRA and Springer-Verlag France SAS 2017

\begin{abstract}
Rice paddies are a major source of methane. How to reduce the methane emission in the paddy field without decreasing the yield has become a major concern of scientists, environmental groups, and agricultural policymakers worldwide. Azolla, used as a dual crop in rice cultivation, has multiple agronomic benefits. However, the effects of the dual cropping of Azolla on methane emissions of double rice cropping paddies have not yet been reported. Here, we conducted a 3-year field experiment to evaluate the impacts of rice + Azolla on methane emission and rice yield in a double rice cropping system. The results indicated that the rice + Azolla without $\mathrm{N}$ fertilizer and with moderate $\mathrm{N}$ fertilizer (200 $\mathrm{kg} \mathrm{N} \mathrm{ha}^{-1} \mathrm{a}^{-1}$ ) significantly reduced methane emissions over the rice cycle by 12.3 and $25.3 \%$ compared with the conventional rice cropping with common $\mathrm{N}$ fertilizer (400 $\mathrm{kg} \mathrm{N} \mathrm{ha}^{-1} \mathrm{a}^{-1}$ ), respectively. The reason for the trend was because the dual cropping of Azolla has significant effect on dissolved oxygen and soil redox potential, which are key factors for methane emission in this study. The rice yield under the rice + Azolla with moderate $\mathrm{N}$ fertilizer annually averaged 12.7 $\mathrm{Mg} \mathrm{ha}^{-1}$, which was comparable with that of the conventional rice cropping with common $\mathrm{N}$ fertilizer. Moreover, the rice + Azolla with moderate $\mathrm{N}$ fertilizer had the lowest yieldscaled methane $\left(25.2 \mathrm{~kg} \mathrm{Mg}^{-1}\right.$ grain yield). Here, we showed
\end{abstract}

Zhaohai Zeng

zengzhaohai@cau.edu.cn

1 College of Agronomy and Biotechnology, China Agricultural University, No. 2 Yuanmingyuan West Road, Haidian District, Beijing 100193, People's Republic of China

2 College of Agriculture, Yangtze University, Jingzhou 434025, People's Republic of China

3 Department of Plant and Environmental Science, Faculty of Science, University of Copenhagen, Copenhagen, Denmark for the first time that Azolla planting allows sustainable rice production coupled with methane mitigation in double rice cropping systems.

Keywords Azolla - Double rice cropping · Grain yield · Methane

\section{Introduction}

Methane $\left(\mathrm{CH}_{4}\right)$ is an important trace gas that contributes to global warming (Montzka et al. 2011), with a 100-year scaled global warming potential (GWP) 28 times the forcing radiative intensity of $\mathrm{CO}_{2}$ on a per mass basis (Myhre et al. 2013). The atmospheric concentration of $\mathrm{CH}_{4}$ risen from $722 \mathrm{ppb}$ in 1750 to $1803 \mathrm{ppb}$ in 2010 (Myhre et al. 2013). Rice paddies are a significant source of atmospheric $\mathrm{CH}_{4}$ and emit between 33 and $40 \mathrm{Tg} \mathrm{CH}_{4}$ annually, accounting for $10-12 \%$ of global anthropogenic $\mathrm{CH}_{4}$ (Ciais et al. 2013). Major concern exists regarding $\mathrm{CH}_{4}$ emissions from rice paddies, and these emissions will continue to increase as rice production intensifies (Hussain et al. 2015).

To meet the food demand of the growing population, rice production is projected to increase from 571.9 million tons in 2001 to 771.1 million tons by 2030 (Nguyen and Ferrero 2006). In China, the production of rice accounts for $35 \%$ of the global production, and China's 30 million ha of riceplanting land accounts for approximately $20 \%$ of the world's total (FAO 2013). An annual double rice cropping system (planting two successive rice crops in 1 year) was established and is popular in southern China; the planting area there represents $56 \%$ of the total national paddy fields (Frolking et al. 2002). Generally, rice intensification requires synthetic fertilizers to achieve higher grain yields. However, the overuse of synthetic fertilizers has many adverse consequences, such as 
the eutrophication of surface water, greenhouse gas emissions, and soil acidification (Shang et al. 2011; Zhang et al. 2013). To produce more rice and simultaneously reduce agricultural environmental harm is the greatest challenge that contemporary agriculture confronts.

Decreasing synthetic fertilizer application and increasing organic matter amendments have drawn recent attentions. The free-floating water fern Azolla occurs in symbiotic association with a nitrogen-fixing cyanobacterium generally refers to as Anabaena azollae. Azolla has been used extensively and effectively as green manure in paddy fields (Bharati et al. 2000; Chen et al. 1997; Ying et al. 2000). As a green manure, Azolla could be either incorporated into paddy soil at the beginning of land preparation for rice planting or grown as a dual crop along with rice plants Fig. 1. Over the past decades, the beneficial effects of Azolla as a green manure in rice cultivation have been widely discussed (Kollah et al. 2016; Vlek et al. 1995). Dual cropping of Azolla exerts various influences on $\mathrm{CH}_{4}$ emissions, mainly by regulating the soil physical-chemical properties. However, the $\mathrm{CH}_{4}$ emissions influenced by the dual cropping of Azolla during double rice growth were poorly reported. Although several observations were made, mainly on single rice (Bharati et al. 2000; Chen et al. 1995, 1997; Ying et al. 2000) or early rice of a double rice cropping system (Ma et al. 2012), no consensus exists regarding the impact of growing Azolla on $\mathrm{CH}_{4}$ emissions in paddy fields. Bharati et al. (2000) and Ma et al. (2012) reported that dual cropping of Azolla decreased significantly $\mathrm{CH}_{4}$ emissions from paddy fields. Bharati et al. (2000) found that mitigation of $\mathrm{CH}_{4}$ emission associated with the presence of Azolla could be related to the increase in dissolved oxygen (DO) content in the standing water, resulting in less reduced paddy soils. Azolla with a higher photosynthetic capacity (Wagner 1997) might release sufficient oxygen into the standing water and soil (Bharati et al. 2000), which makes paddy soil less reduced. The activity of $\mathrm{CH}_{4}$-producing bacteria in paddy soil is inhibited by exposure to less reduced paddy soils (Conrad 2002). Conversely, increased DO oxidizes paddy soils and stimulates methanotrophic bacteria to consume $\mathrm{CH}_{4}$ (Aulakh et al. 2001). A large proportion of the $\mathrm{CH}_{4}$ produced may become oxidized beneath the plants due to the accumulation of $\mathrm{CH}_{4}$ as a result of a decrease in the diffusion. Moreover, ebullition through bubbles is a common and significant mechanism of $\mathrm{CH}_{4}$ transport, and less than $10 \%$ of $\mathrm{CH}_{4}$ are diffused through ebullition (Aulakh et al. 2001). Azolla floats on the water's surface and forms a mass with a large percentage of cover on the water surface of paddy fields. This Azolla cover might serve as a physical barrier that prevents $\mathrm{CH}_{4}$ transport through ebullition (Ma et al. 2012; Wang et al. 2015). The free-floating plants retard $\mathrm{CH}_{4}$ transport through bubble ebullitive (Kosten et al. 2016). As we known, $\mathrm{CH}_{4}$ emission is the net product of $\mathrm{CH}_{4}$ production, oxidation, and transport in the rice soilplant system (Conrad 2002). These effects are the benefits of mitigation of $\mathrm{CH}_{4}$ emissions from paddy fields.

On the contrary, Ying et al. (2000) and Chen et al. (1995, 1997) reported that a dual cropping of Azolla greatly increases $\mathrm{CH}_{4}$ emissions from paddy fields. Ying et al. (2000) found a significant decrease in DO concentration in surface water and an increase in $\mathrm{NH}_{4}{ }^{+}-\mathrm{N}$ content in paddy soil due to the presence of Azolla, which enhanced $\mathrm{CH}_{4}$ production and inhibited $\mathrm{CH}_{4}$ oxidation, thereby leading to an increase in $\mathrm{CH}_{4}$ emissions. Otherwise, the exudation of Azolla root and the decomposition of dead Azolla could offer abundant substrates for methanogens and hence $\mathrm{CH}_{4}$ production (Chen et al. 1997). In addition, Ying et al. (2000) reported that Azolla mediates $\mathrm{CH}_{4}$ transport from the floodwater of a rice soil into the atmosphere just as rice plants did.

The benefits of the rice + Azolla cropping system with respect to decreasing $\mathrm{N}$ fertilizer application and mitigating $\mathrm{CH}_{4}$ emissions are unknown in double rice cropping systems. The current experiment will provide unique insights regarding the rice + Azolla farming system in double rice cropping systems in southern China. The objectives of the study were to (1) estimate the effect of a dual cropping of Azolla along with double rice on $\mathrm{CH}_{4}$ emissions from double rice cropped fields in southern China and (2) to clarify the mechanism underlying the impacts of Azolla on $\mathrm{CH}_{4}$ emission.
Fig. 1 Planting patterns of a the conventional rice cultivation system and $\mathbf{b}$ the rice + Azolla cropping system
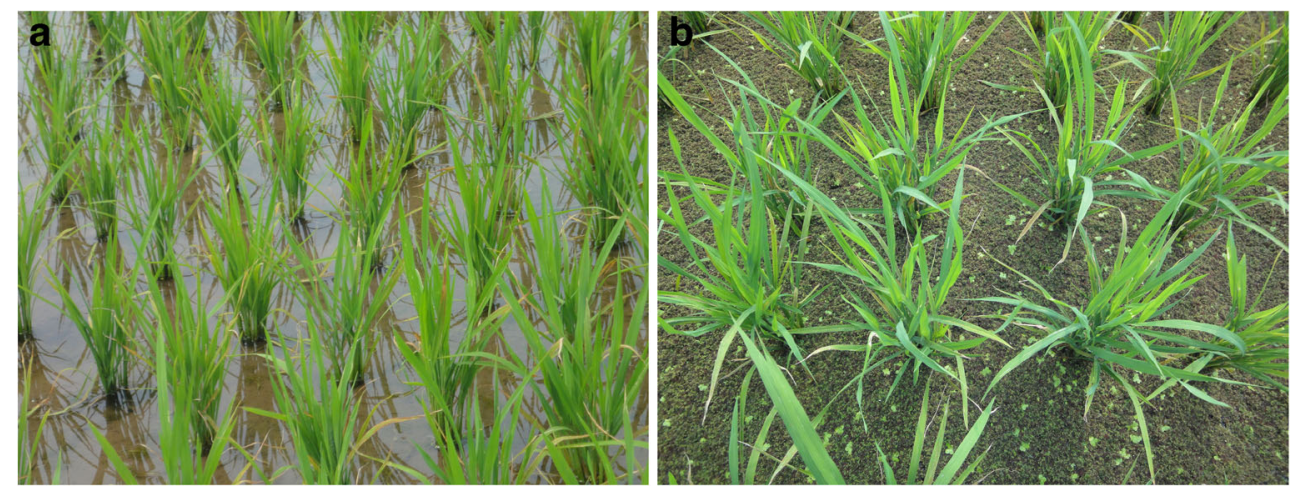


\section{Materials and methods}

\subsection{Site description}

A consecutive 3-year field experiment was conducted at the experimental farm of the Soil and Fertilizer Institute of Hunan Academy of Agricultural Sciences from 2012 to 2014. This farm is located in Wanyu $\left(29^{\circ} 34^{\prime} \mathrm{N}\right.$ latitude, $112^{\circ} 49^{\prime} \mathrm{E}$ longitude), Huarong County, Hunan Province, southern China. The region belongs to the Dongting Lake Plain, which has a typical subtropical monsoon climate with an average temperature of $16-18^{\circ} \mathrm{C}$, a total rainfall of $1200-1700 \mathrm{~mm}$, 262 frost-free days, and up to $1516.8 \mathrm{~h}$ of annual sunshine. The soil is purple calcareous clayey paddy soil developed from lake deposits. The initial properties of the paddy soil (0-20-cm depth) were sand $28.5 \%$, silt $56.8 \%$, clay $16.7 \%$, bulk density $1.27 \mathrm{~g} \mathrm{~cm}^{-3}$, organic carbon content $29.2 \mathrm{~g} \mathrm{~kg}^{-1}$, $\mathrm{pH}\left(\mathrm{H}_{2} \mathrm{O}\right) 7.7$, total nitrogen $2.95 \mathrm{~g} \mathrm{~kg}^{-1}$, available phosphorus $16.4 \mathrm{mg} \mathrm{kg}^{-1}$, and exchangeable potassium $69 \mathrm{mg} \mathrm{kg}^{-1}$.

\subsection{Experimental setup and field-management practices}

The experiment consisted of four treatments: the conventional rice cultivation without $\mathrm{N}$ fertilizer, the conventional rice cultivation with common $\mathrm{N}$ fertilizer $\left(200 \mathrm{~kg} \mathrm{~N} \mathrm{ha}^{-1}\right)$, the rice + Azolla without $\mathrm{N}$ fertilizer, and the rice + Azolla with moderate $\mathrm{N}$ fertilizer $\left(100 \mathrm{~kg} \mathrm{~N} \mathrm{ha}^{-1}\right)$. The common $\mathrm{N}$ fertilizer application at a typical rate of $200 \mathrm{~kg} \mathrm{~N}^{-1}$ per season was in line with the local application rate. The treatments were arranged in a completely randomized block design with three replications. Twelve plots of $30 \mathrm{~m}^{2}(5 \times 6 \mathrm{~m})$ per individual plot were used.

$\mathrm{N}$ fertilizer (urea) was applied in two split doses: $70 \%$ as basal fertilizer and $30 \%$ as topdressing approximately 25 days after rice seedling transplanting. A total of $85 \mathrm{~kg} \mathrm{P}_{2} \mathrm{O}_{5} \mathrm{ha}^{-1}$ (calcium super-phosphate) was applied in two split doses for all plots: $75 \mathrm{~kg} \mathrm{ha}^{-1}$ as basal fertilizer and $10 \mathrm{~kg} \mathrm{ha}^{-1}$ as topdressing 1 day after Azolla inoculation. A total of $100 \mathrm{~kg}$ $\mathrm{K}_{2} \mathrm{O}$ ha $^{-1}$ (potassium chloride) was used as basal fertilizer. Basic fertilizers were applied 1 day before rice transplanting. In accordance with the local water regime, flooding was initiated 3-4 days prior to rice seedling transplanting and maintained for approximately 30 days until midseason drainage to aerate the paddy soils.

\subsection{Crop management}

The double rice cropping system is widely practiced in southern China, especially in the rice-producing area of the middle and lower reaches of the Yangtze River. In the current study, the typical rice-rice-fallow farming system was adopted. The 30-day-old early rice seedlings (cv. T-Liangyou 705) were transplanted in late April and harvested in middle July, and 30-day-old late rice seedlings (cv. Yueyou 9113) were transplanted in middle or late July and harvested in late October.

The fresh Azolla caroliniana was used, with 2.23$2.84 \%$ total carbon and $0.22-0.29 \%$ nitrogen, and broadcast into the floodwater surface at a rate of $1000 \mathrm{~kg} \mathrm{ha}^{-1}$ 7 days after early and late rice transplanting. Initially, Azolla was inoculated into Azolla-treated plots with a percentage of $12 \%$ surface cover of flooding water. A 5- to 7 $\mathrm{cm}$ depth of standing water was maintained to facilitate Azolla growth before midseason drainage. Azolla grew rapidly and held a biomass up to $6802 \pm 243 \mathrm{~kg} \mathrm{ha}^{-1}$ with greater than $79-88 \%$ of flooding water surface less than 14 days after inoculation during the early rice seasons of 2012-2014. In the late rice season, the Azolla grew slowly due to high air temperature and the fresh biomass of all the Azolla-treated plots was increased to $6293 \pm 356 \mathrm{~kg} \mathrm{ha}^{-1}$ with approximately $73-84 \%$ coverage on the surface water until 20 days after inoculation. Thereafter, rice fields were waterlogged and a water regime of alternating wet-drought cycles was adopted until 7 days prior to rice harvest. Notably, most of the Azolla died off due to drought during the midseason drainage period, but a small amount of Azolla survived. At the end of the midseason drainage when paddy soils were waterlogged again, Azolla floated on the floodwater, grew well, and reproduced rapidly.

\section{4 $\mathrm{CH}_{4}$ flux measurements}

$\mathrm{CH}_{4}$ flux was determined using a closed chamber/gas chromatography method (Zou et al. 2005). The closed static chambers $(50 \times 50 \times 100 \mathrm{~cm})$ were made of transparent Perspex. Removable wooden boardwalks ( $2 \mathrm{~m}$ in length) were installed before gas sampling to avoid disturbing the paddy soil in all of the plots. Four rice hills were covered to measure $\mathrm{CH}_{4}$. Sampling events were conducted in the morning (9:0011:00) on every sampling day. A battery-operated fan was mounted on the top of the chamber to mix the interior air. Gas samples were then drawn off with a syringe with a 25$\mathrm{ml}$ volume at 10 -min intervals (i.e., $0,10,20$, and $30 \mathrm{~min}$ after closure) and immediately transferred into $18-\mathrm{ml}$ vacuumed vials. After each sampling event, the chambers were removed from their bases. The air temperature inside the chamber was recorded using a manual thermocouple thermometer (JM624, Tianjin Instrument Co. Ltd., Tianjin, China). On average, $\mathrm{CH}_{4}$ flux measurements were recorded every $3-5$ days during the early and late rice seasons. During the early stage (from shortly after transplanting to the midseason drainage) of the early and late rice seasons, the sampling event was more frequent than the late stage, and the sampling event was stopped 37 days prior to harvest. 
We measured $\mathrm{CH}_{4}$ concentration using a modified gas chromatograph (Agilent 7890A, CA, USA) equipped with a flame-ionization detector (FID) and a Porapak Q column (6 ft. long, 1/8 in. outer diameter, 80/100 mesh size, stainless steel column). The temperatures of the injector, column, and detector were maintained at 150,50 , and $230^{\circ} \mathrm{C}$, respectively.

\subsection{Auxiliary measurements}

The dissolved oxygen concentration at the soil-flood water and soil redox potential were measured at the same time as $\mathrm{CH} 4$ emissions were monitored. In the duration of midseason drainage, the standing water was withdrawn, and therefore, the DO measurements were paused. The dissolved oxygen concentration at the soil-flood water interface was determined using a portable dissolution oxygen meter (HI9143, HANNA Instrument, Italy). Soil redox potential $\left(E_{h}\right)$ was measured by portable $E_{h}$ meter (Chuan-Di Instrument \& Equipment Co., Ltd., Nanjing, China), using the depolarization method. The platinum electrode was inserted in the soil at known depths at $10 \mathrm{~cm}$. The rice grain yields were determined at harvest via oven drying to a constant weight at approximately $75^{\circ} \mathrm{C}$.

\subsection{Data analyses}

Fluxes of $\mathrm{CH}_{4}(F)$ were computed based on the change in concentration $(\Delta c)$ over a period of time $(\Delta t)$. Sample sets were rejected unless they yielded an $R^{2}$ value of greater than 0.90 (Mosier et al. 2006). Cumulative $\mathrm{CH}_{4}$ emissions over the entire rice season were estimated via the trapezoidal integration of the mean flux over time (Mosier et al. 2006)

$F=\rho \times(V / A) \times(\Delta c / \Delta t) \times 273 /(273+T)$

$R_{\mathrm{CH}_{4}}=\sum_{i=1}^{n}(F i \times D i \times 24)$

where $V$ is the volume of the static chamber above the enclosed soil with surface area $(A), \rho$ is the density of $\mathrm{CH}_{4}$, $T$ is the mean temperature $\left({ }^{\circ} \mathrm{C}\right), R_{\mathrm{CH} 4}$ is the cumulative $\mathrm{CH}_{4}$ emission per rice season, $F i$ is the average of two adjacent intervals of the measurements, $D i$ is the interval in days of the adjacent two sampling dates, and 24 are the hours in 1 day.

The collected data were analyzed using the PROC ANOVA procedure in SAS version 9.3 (SAS Institute Inc., Cary, NC, USA). Multiple comparisons among treatment means were conducted using the least significant difference (LSD) test depending on the number of treatment means compared. Tests of the significance among treatments were based on a probability level of 5\%. A linear regression analysis was used to clarify the correlations between the $\mathrm{N}$ fertilizer application and cumulative seasonal $\mathrm{CH}_{4}$ emissions. SigmaPlot version
12.5 (Systat Software Inc. San Jose, CA, USA) was employed for figure preparation.

\section{Results and discussion}

\section{1 $\mathrm{CH}_{4}$ emissions}

Across 3-year measurements, the $\mathrm{CH}_{4}$ effluxes ranged respectively from -1.96 to $47.70 \mathrm{mg} \mathrm{m}^{-2} \mathrm{~h}^{-1}$ for early rice and from -2.50 to $93.45 \mathrm{mg} \mathrm{m}^{-2} \mathrm{~h}^{-1}$ for late rice (Fig. 2a). Similar patterns of $\mathrm{CH}_{4}$ emissions for all treatments were observed during the early and late rice growing seasons. In the current study, two major peaks of $\mathrm{CH}_{4}$ emission were observed for all treatments in the rice seasons of 2012, 2013, and 2014 (Fig. 2a). The first major $\mathrm{CH}_{4}$ emission peaks during the early and late rice seasons occurred in late May and early August when rice plants were at the tillering stage, when the paddy soil redox potential declined to very low value (Fig. 2c) due to consumption of the oxygen in the standing water (Fig. 2d). In addition, the $\mathrm{CH}_{4}$ emission peaks could be associated with the increased availability of organic matter derived from the microbial decomposition of leftover plant residues (Conrad 2002; Hussain et al. 2015). In the duration of midseason drainage, $\mathrm{CH}_{4}$ effluxes declined to approximately zero and even below (Fig. 2a). The reason for the low $\mathrm{CH}_{4}$ effluxes could be associated with higher soil redox potential. During the midseason drainage, the standing water was withdrawn and paddy soil was aerated and thereby the soil redox status was improved, reflecting the higher soil redox potential. High soil redox potential could inhibit $\mathrm{CH}_{4}$ production and contribute to $\mathrm{CH}_{4}$ oxidation and hence lower $\mathrm{CH}_{4}$ emission rate (Malyan et al. 2016). Other minor $\mathrm{CH}_{4}$ emission peaks were observed, respectively, in late June and early or middle September during the early and late rice growing seasons when rice plants were in their flowering stages. Besides low soil redox potential (Fig. 2c) and dissolved oxygen concentration in the standing water (Fig. 2d), the minor $\mathrm{CH}_{4}$ peaks might be ascribed to the increased substrates from the root exudates from vigorous roots of developed rice plants.

In response to the temporal change in $\mathrm{CH}_{4}$ effluxes, the pattern of the cumulative $\mathrm{CH}_{4}$ emissions per rice crop season was divided into three distinct phases: the rapid increase from transplanting to midseason drainage, the near-zero growth phase during the midseason drainage, and the slow increasing phase from the end of midseason drainage to rice maturity (Fig. 2b). Over the early and late rice growing seasons, the $\mathrm{CH}_{4}$ emissions varied from 108.3 to $212.4 \mathrm{~kg} \mathrm{ha}^{-1}$ and from 164.3 to $345.9 \mathrm{~kg} \mathrm{ha}^{-1}$, respectively (Fig. 2b). These values were within the magnitude range of $3-2050 \mathrm{~kg} \mathrm{ha}^{-1}$ estimated by Cai et al. (2000) in major Chinese rice fields.

Across all treatments, the maximum cumulative $\mathrm{CH}_{4}$ emission was observed under the conventional rice cropping without 
Fig. 2 Seasonal variations in $\mathrm{CH}_{4}$ fluxes (a), cumulative $\mathrm{CH}_{4}$ emissions (b), soil redox potential (c), and dissolved oxygen concentration in surface water (d) during the early and late rice growing seasons from 2012 to 2014. RAN0 represents the rice + Azolla without N fertilizer, RMN0 represents the conventional rice without $\mathrm{N}$ fertilizer, RAN1 represents the rice + Azolla with moderate $\mathrm{N}$ fertilizer at $100 \mathrm{~kg} \mathrm{ha}^{-1} \mathrm{~N}$, and RMN2 represents the conventional rice with common $\mathrm{N}$ fertilizer at $200 \mathrm{~kg} \mathrm{ha}^{-1} \mathrm{~N}$. The data shown in the panel are averages of the three replicates for individual treatment. Vertical bars represent the standard errors of the three replicates
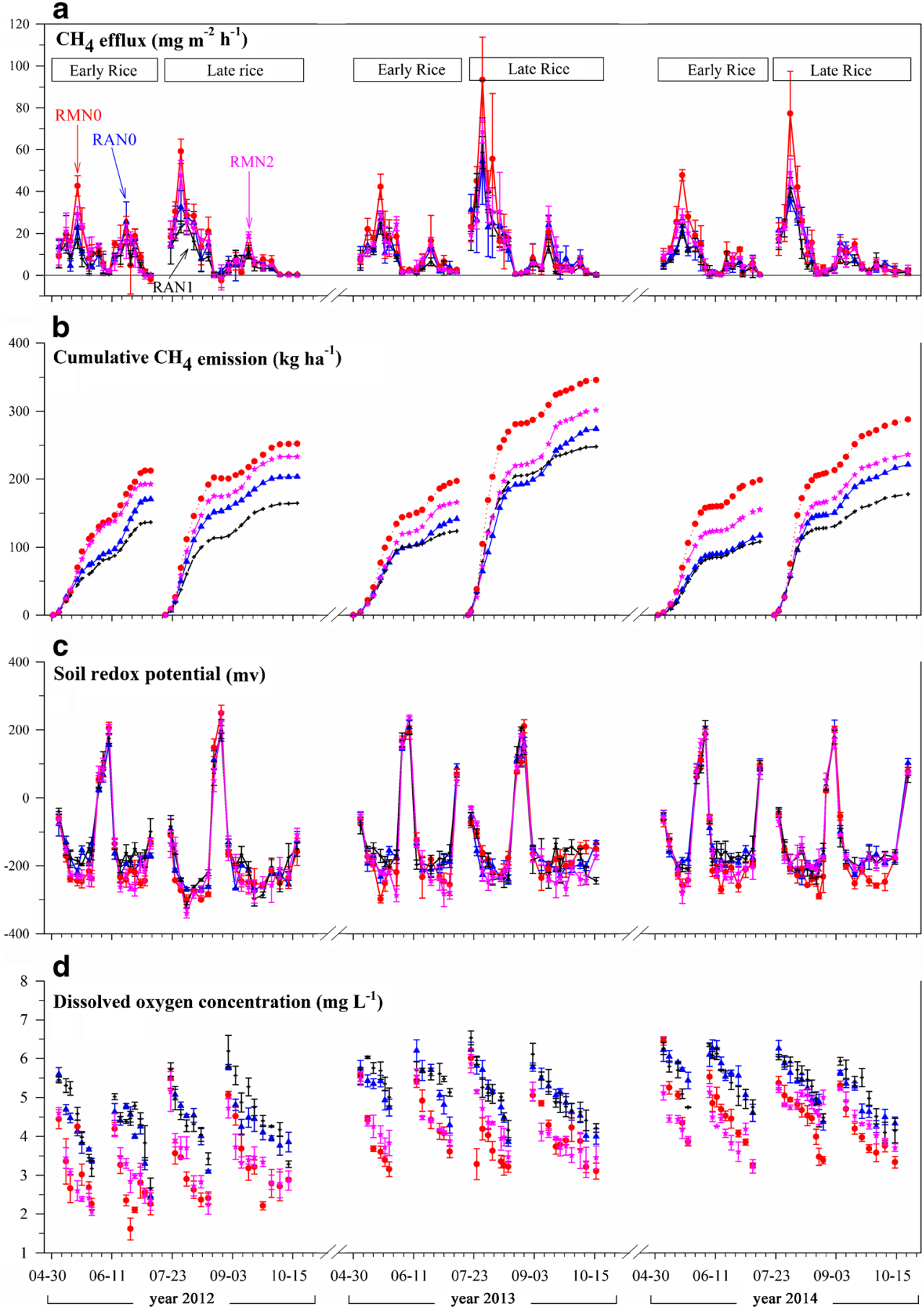

$\mathrm{N}$ fertilizer, whose $\mathrm{CH}_{4}$ emissions were 196.8-212.4 and 252.3$345.9 \mathrm{~kg} \mathrm{ha}^{-1}$ over the early and late rice seasons, respectively (Fig. 2b). In comparison with the conventional rice cropping without $\mathrm{N}$ fertilizer, the rice + Azolla without $\mathrm{N}$ fertilizer decreased drastically $\mathrm{CH}_{4}$ emissions by $19.8-40.9$ and 19.3$23.0 \%$ during the early and late rice seasons, respectively (Fig. $2 \mathrm{~b}$ ). The results were supported by a previous study (Ma et al. 2012). Ma et al. (2012) found that a $20.4 \%$ decrease in $\mathrm{CH}_{4}$ emission associated with the presence of Azolla compared with the plots without Azolla in subtropical paddy fields in Fuzhou Plain, southern China. The low $\mathrm{CH}_{4}$ flux from the plots with Azolla could be a combination of higher dissolved oxygen content in the standing water and soil redox potential. In the current experiment, compared with the conventional rice without $\mathrm{N}$ fertilizer, the rice + Azolla without $\mathrm{N}$ fertilizer markedly enhanced the dissolved oxygen at the soil-water interface by $30.0-42.8$ and $24.1-44.8 \%$ in the early and late rice seasons, respectively (Fig. 2d). The leaching of oxygenated water by percolation in 
flooded paddy soil would inhibit methane-oxidizing bacteria through improvement of soil redox status. In this study, the rice + Azolla without $\mathrm{N}$ fertilizer enhanced the soil redox potential by 14.5-19.8 and 12.7-19.4\% during the early and late rice growing seasons, respectively (Fig. 2c). Earlier study demonstrated that Azolla with the high photosynthesis capacity could release abundant oxygen into the standing water (Wagner 1997), and hence increased dissolved oxygen concentration. Similarly, previous studies reported that growing Azolla increased dissolved oxygen concentration in the standing water and improved the soil redox status (Bharati et al. 2000; Ma et al. 2012). High dissolved oxygen in the standing water might retard $\mathrm{CH}_{4}$ emission from rice field by promoting $\mathrm{CH}_{4}$ oxidation at the soil-water interface (Kosten et al. 2016; Conrad 2002). We found that $\mathrm{CH}_{4}$ efflux was negatively correlated with dissolved oxygen concentration in standing water $(r=-0.653, P<0.001$; Fig. 3a). Additionally, a strong inverse relationship between $\mathrm{CH}_{4}$ efflux and soil redox potential was observed in this study $(r=-0.712, P<0.0001$; Fig. $3 b)$. Further reduction in $\mathrm{CH}_{4}$ emission was observed under the rice + Azolla with moderate $\mathrm{N}$ fertilizer at $100 \mathrm{~kg} \mathrm{~N} \mathrm{ha}^{-1}$. The rice + Azolla with moderate $\mathrm{N}$ fertilizer application inhibited $\mathrm{CH}_{4}$ emissions by $25.2-30.2$ and $17.8-29.5 \%$ during the early and late rice, respectively, compared with the conventional rice with common $\mathrm{N}$ fertilizer (Fig. 2b). The rice + Azolla with $\mathrm{N}$ fertilizer at $100 \mathrm{~kg} \mathrm{~N}$ ha $^{-1}$ slightly increased the dissolved oxygen concentration in the standing water (Fig. 2d) and soil redox potential (Fig. 2c). In addition, the Azolla in conjunction with urea $\mathrm{N}$ might have stronger capacity to oxidize methane compared with Azolla only (Prasanna et al. 2002). In the current study, $\mathrm{N}$ fertilizer application decreased $\mathrm{CH}_{4}$ emissions from double rice cropping paddies. The conventional rice with common $\mathrm{N}$ fertilizer decreased $\mathrm{CH}_{4}$ emissions by $9.4-21.8$ and 7.6$17.9 \%$ during early and late rice seasons relative to the conventional rice without $\mathrm{N}$ fertilizer, which aligns with the findings of previous studies (Xie et al. 2009; Yao et al. 2012; Zou et al. 2005). In contrast, a pot experiment

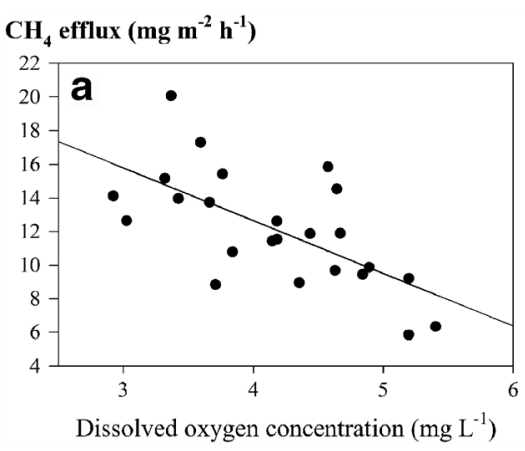

Fig. 3 Correlation between the average $\mathrm{CH}_{4}$ efflux and corresponding dissolved oxygen concentration (a) and soil redox potential (b). RAN0 represents the rice + Azolla without $\mathrm{N}$ fertilizer, RMN0 represents the conventional rice without $\mathrm{N}$ fertilizer, RAN1 represents the rice + Azolla with moderate $\mathrm{N}$ fertilizer at $100 \mathrm{~kg} \mathrm{ha}^{-1} \mathrm{~N}$, and RMN2 represents the conventional rice with common $\mathrm{N}$ fertilizer at conducted by Ying et al. (2000) found that the pots with Azolla decreased remarkably the dissolved oxygen concentration in standing water relative to the pots without Azolla. Such discrepancy might be the limit of pot experiment.

\subsection{Rice yields and yield-scaled $\mathrm{CH}_{4}$ emissions}

Across the 3-year measurements, grain yields of early rice ranged from 3.4 to $6.0 \mathrm{Mg} \mathrm{ha}^{-1}$, whereas those of late rice ranged from 5.3 to $8.4 \mathrm{Mg} \mathrm{ha}^{-1}$ (Fig. 4). In the present study, the dual cropping of Azolla positively affected the rice yields of both seasons. The rice + Azolla without $\mathrm{N}$ fertilizer increased rice yields by $2.3-12.7$ and $3.0-4.6 \%$ for early and late rice, respectively, compared with the conventional rice without $\mathrm{N}$ fertilizer across the 3-year experiment (Fig. 4). Except for the early rice yield in 2012, no significant difference was observed between these conditions (Fig. 4). This might be $\mathrm{N}$ supply by Azolla through the biological $\mathrm{N}$ fixation. The daily rate of $\mathrm{N}$ fixation was estimated as $0.6-0.7 \mathrm{~kg} \mathrm{ha}^{-1}$ (Cissé and Vlek 2003b), and thereby, the biological $\mathrm{N}$ fixation amounted to $45 \mathrm{~kg} \mathrm{~N} \mathrm{ha}^{-1}$ each season in the current experiment. Earlier studies have demonstrated that dual cropping of Azolla increases rice yields (Bharati et al. 2000; Fosu-Mensah et al. 2015). As reviewed by Kollah et al. (2016), N supply due to Azolla through biological nitrogen fixation might be associated with the increase in grain yields. The rice + Azolla with moderate $\mathrm{N}$ fertilizer had a positive and significant influence on grain yields. Over the 3 -year measurement, the rice + Azolla with moderate $\mathrm{N}$ fertilizer increased significantly grain yields by $21.1-35.3 \%$ compared with the conventional rice without $\mathrm{N}$ fertilizer (Fig. 4). As expected, $\mathrm{N}$ fertilizer application stimulated rice growth and enhanced rice yields. Based on the annual rice cycle, over the 3-year average, the grain yield of the rice + Azolla with moderate $\mathrm{N}$ fertilizer totalled $12.7 \pm 0.9 \mathrm{Mg} \mathrm{ha}^{-1}$, which was only $8.6 \%$ lower than that of the conventional rice with common $\mathrm{N}$ fertilizer (Table 1). The conventional rice cultivation with common $\mathrm{N}$ fertilizer led to

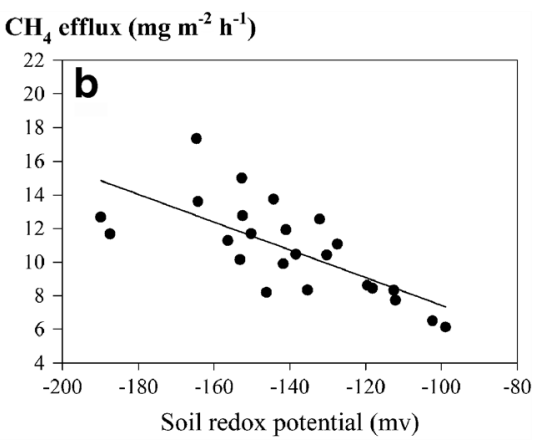

$200 \mathrm{~kg} \mathrm{ha}^{-1} \mathrm{~N}$. The correlation shows a tendency for the seasonal $\mathrm{CH}_{4}$ emissions to decrease with the either increase in dissolved oxygen concentration or soil redox potential. For dissolved oxygen concentration, $y=-3.13 x+25.19(n=24, r=-0.653, P<0.001)$; for soil redox potential, $y=-0.083 x-0.806(n=24, r=-0.712, P<0.001)$ 


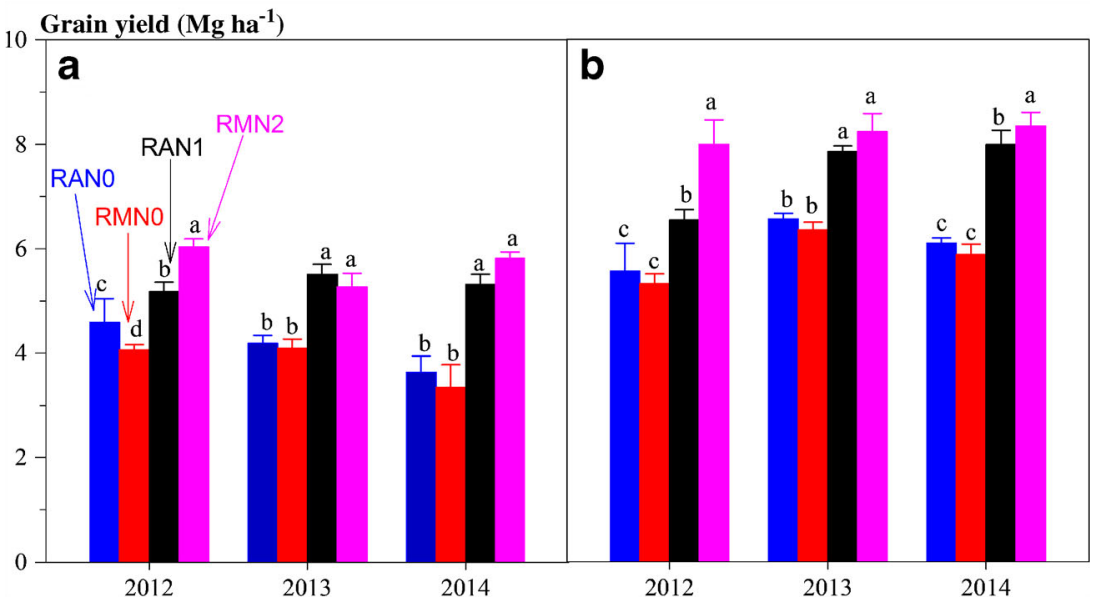

Fig. 4 Rice grain yields for early (a) and late (b) rice from 2012 to 2014. RAN0 represents the rice + Azolla without $\mathrm{N}$ fertilizer, RMN0 represents the conventional rice without $\mathrm{N}$ fertilizer, RAN1 represents the rice + Azolla with moderate $\mathrm{N}$ fertilizer at $100 \mathrm{~kg} \mathrm{~N} \mathrm{ha}^{-1}$, and RMN2

represents the conventional rice with common $\mathrm{N}$ fertilizer at $200 \mathrm{~kg}$ $\mathrm{N} \mathrm{ha}^{-1}$. The data shown in the panel are averages of the three replicates for individual treatment. Vertical bars represent the standard errors. Different lowercase letters represent the significant differences at $P<0.05$

the highest rice grain yields, with 3-year averages of $5.7 \pm 0.3 \mathrm{Mg} \mathrm{ha}^{-1}$ for early rice and $8.21 \pm 0.4 \mathrm{Mg} \mathrm{ha}^{-1}$ for late rice (Fig. 4 and Table 1). The grain yields of the rice + Azolla with moderate $\mathrm{N}$ fertilizer were comparable to those of the conventional rice with common $\mathrm{N}$ fertilizer, decreased grain yields of early and late rice by 7.0 and $9.8 \%$, respectively (Table 1). This might be Azolla $\mathrm{N}$ supply and the conservation of urea $\mathrm{N}$ via immobilization-remobilization in the presence of Azolla enhanced N availability for rice plants (Cissé and Vlek 2003a), and thereby increased rice growth. The results were interesting regarding the $50 \%$ reduction in synthetic $\mathrm{N}$ fertilizer. The application of $\mathrm{N}$ fertilizer enhanced rice grain yields in our study, as other works have reported (Zou et al. 2005). A significant increase was observed in grain yields when synthetic $\mathrm{N}$ was applied, regardless of the dual cropping of Azolla.
To better evaluate the rice + Azolla cropping system, it is important to consider options that have the potential to improve rice production and reduce $\mathrm{CH}_{4}$ emission. Yield-scaled $\mathrm{CH}_{4}$ emission was previously introduced to evaluate $\mathrm{CH}_{4}$ emission and rice yields (Mosier et al. 2006). Based on the annual rice cycle, the lowest yield-scaled $\mathrm{CH}_{4}$ emission was determined with regard to the rice + Azolla with moderate $\mathrm{N}$ fertilizer $\left(25.2 \pm 2.9 \mathrm{~kg} \mathrm{Mg}^{-1}\right.$ grain yield $)$ and followed in ascending order by the conventional rice with common $\mathrm{N}$ fertilizer (30.8 $\pm 3.4 \mathrm{~kg} \mathrm{Mg}^{-1}$ grain yield), the rice + Azolla without $\mathrm{N}$ fertilizer $\left(37.2 \pm 2.7 \mathrm{~kg} \mathrm{Mg}^{-1}\right.$ grain yield), and the conventional rice without $\mathrm{N}$ fertilizer $\left(51.3 \pm 3.6 \mathrm{~kg} \mathrm{Mg}^{-1}\right.$ grain yield) (Table 1). Similarly, Bharati et al. (2000) found that the lowest yield-scaled $\mathrm{CH}_{4}$ emission $\left(20.6 \mathrm{~kg} \mathrm{CH}_{4} \mathrm{Mg}^{-1}\right.$ grain yield) was associated with the plot with the Azolla dual crop, supporting our findings. However, the rice + Azolla

Table 1 The 3-year (from 2012 to 2014) average grain yields, $\mathrm{CH}_{4}$ emissions, and yield-scaled $\mathrm{CH}_{4}$ emissions influenced by Azolla as a dual crop combination with urea $\mathrm{N}$

\begin{tabular}{|c|c|c|c|c|c|c|c|}
\hline \multirow[t]{2}{*}{ Treatment } & \multicolumn{2}{|l|}{ Early rice } & \multicolumn{2}{|l|}{ Late rice } & \multicolumn{3}{|c|}{ Annual rice cycle ${ }^{\mathrm{a}}$} \\
\hline & $\begin{array}{l}\text { Grain yield } \\
\left(\mathrm{Mg} \mathrm{ha}^{-1}\right)\end{array}$ & $\begin{array}{l}\mathrm{CH}_{4} \text { emission } \\
\left(\mathrm{kg} \mathrm{ha}^{-1}\right)\end{array}$ & $\begin{array}{l}\text { Grain yield } \\
\left(\mathrm{Mg} \mathrm{ha}^{-1}\right)\end{array}$ & $\begin{array}{l}\mathrm{CH}_{4} \text { emission } \\
\left(\mathrm{kg} \mathrm{ha}^{-1}\right)\end{array}$ & $\begin{array}{l}\text { Grain yield } \\
\left(\mathrm{Mg} \mathrm{ha}^{-1}\right)\end{array}$ & $\begin{array}{l}\mathrm{CH}_{4} \text { emission } \\
\left(\mathrm{kg} \mathrm{ha}^{-1}\right)\end{array}$ & $\begin{array}{l}\text { Yield-scaled } \mathrm{CH}_{4}\left(\mathrm{~kg} \mathrm{Mg}^{-1}\right. \\
\text { grain yield })\end{array}$ \\
\hline RAN0 & $4.1 \pm 0.5 \mathrm{~b}$ & $143.1 \pm 17.2 \mathrm{c}$ & $6.0 \pm 0.5 \mathrm{c}$ & $233.1 \pm 44.3 \mathrm{bc}$ & $10.2 \pm 0.5 \mathrm{c}$ & $376.2 \pm 40.1 \mathrm{c}$ & $37.2 \pm 2.7 b$ \\
\hline RAN1 & $5.3 \pm 0.2 \mathrm{a}$ & $123.0 \pm 11.1 \mathrm{~d}$ & $7.5 \pm 0.7 \mathrm{~b}$ & $196.7 \pm 47.5 \mathrm{c}$ & $12.7 \pm 0.9 \mathrm{~b}$ & $319.7 \pm 42.0 \mathrm{~d}$ & $25.2 \pm 2.9 \mathrm{~d}$ \\
\hline RMN0 & $3.8 \pm 0.4 \mathrm{~b}$ & $202.5 \pm 26.4 \mathrm{a}$ & $5.9 \pm 0.5 \mathrm{c}$ & $295.3 \pm 54.0 \mathrm{a}$ & $9.7 \pm 0.7 \mathrm{~d}$ & $497.9 \pm 44.2 \mathrm{a}$ & $51.3 \pm 3.6 \mathrm{a}$ \\
\hline RMN2 & $5.7 \pm 0.3 \mathrm{a}$ & $171.1 \pm 19.7 \mathrm{~b}$ & $8.2 \pm 0.4 \mathrm{a}$ & $257.2 \pm 45.8 \mathrm{ab}$ & $13.9 \pm 0.4 \mathrm{a}$ & $428.3 \pm 37.2 b$ & $30.8 \pm 3.4 \mathrm{c}$ \\
\hline $\mathrm{LSD}_{0.05}$ & 0.381 & 18.622 & 0.508 & 46.137 & 0.628 & 39.324 & 3.065 \\
\hline
\end{tabular}

Mean \pm SD; different lowercase letters indicate the significant differences $(P<0.05)$ based on LSD multiple range tests. RAN0 represents the rice + Azolla without $\mathrm{N}$ fertilizer, RMN0 represents the conventional rice without N fertilizer, RAN1 represents the rice + Azolla with moderate N fertilizer, and RMN2 represents the conventional rice with common $\mathrm{N}$ fertilizer

${ }^{\mathrm{a}} \mathrm{The} \mathrm{CH}_{4}$ emissions during the winter fallow were near zero. Therefore, the annual emission is equivalent to the sum of the $\mathrm{CH}_{4} \mathrm{emission}$ from the early and late rice paddies 
without $\mathrm{N}$ fertilizer increased the yield-scaled $\mathrm{CH}_{4}$ emissions by $20.8 \%$ relative to the conventional rice with common $\mathrm{N}$ fertilizer (Table 1). In light of sustainable rice production, a dual cropping of Azolla alone is not expected to be adopted in double rice cropping systems in southern China. Annual grain yields of the rice + Azolla with moderate $\mathrm{N}$ fertilizer were up to $12.7 \pm 0.9 \mathrm{Mg} \mathrm{ha}^{-1}$, which was $8.6 \%$ lower than those of the conventional rice with common $\mathrm{N}$ fertilizer; however, the 25.4\% decrease in $\mathrm{CH}_{4}$ emissions is exciting. Above all, a combination dual cropping of Azolla with moderate $\mathrm{N}$ fertilizer had a slight decrease in rice yields versus the conventional rice with common $\mathrm{N}$ fertilizer; however, the effect was compensated by a substantial decrease in $\mathrm{CH}_{4}$ emissions from paddy soils.

\section{Conclusions}

Azolla is applied as a dual crop combined with early and late rice in double rice cropping systems in southern China. The present experiment indicated that dual cropping of Azolla drastically decreases $\mathrm{CH}_{4}$ emissions from double rice cropping paddies relative to the conventional rice cultivation system. Compared with the conventional rice with common $\mathrm{N}$ fertilizer, the rice + Azolla without $\mathrm{N}$ fertilizer and with moderate $\mathrm{N}$ fertilizer decreased $\mathrm{CH}_{4}$ emissions by $11.5-24.5$ and $25.2-30.2 \%$ during the early rice season and by $6.2-12.7$ and $14.8-29.5 \%$ during the late rice season, respectively. The rice + Azolla with moderate $\mathrm{N}$ fertilizer decreased $\mathrm{CH}_{4}$ emission per unit of grain yield. The interaction between the dual cropping of Azolla and $\mathrm{N}$ fertilizer application significantly influenced the maintenance of rice production while mitigating $\mathrm{CH}_{4}$ emissions. Significant reductions in $\mathrm{CH}_{4}$ emissions, considerable decreases in $\mathrm{N}$ fertilization, and comparable rice grain yields indicate that a dual cropping of Azolla combined with $\mathrm{N}$ fertilizer are possible ways to help both rice production and climate change.

Acknowledgments The National Key Technology Research and Development Program of the People's Republic of China (Project No. 2012BAD14B03) provided funding for this project. We thank the anonymous reviewers and editors for their helpful comments and suggestions regarding this manuscript.

\section{References}

Aulakh MS, Wassmann R, Rennenberg H (2001) Methane emissions from rice fields - quantification, mechanisms, role of management, and mitigation options. Adv Agron 70:193-260. doi:10.1016/ S0065-2113(01)70006-5

Bharati K, Mohanty SR, Singh DP, Rao VR, Adhya TK (2000) Influence of incorporation or dual cropping of Azolla on methane emission from a flooded alluvial soil planted to rice in eastern India. Agric Ecosyst Environ 79:73-83. doi:10.1016/S0167-8809(99)00148-6
Cai ZC, Tsuruta H, Minami K (2000) Methane emission from rice fields in China: measurements and influencing factors. J Geophys ResAtmos 105:17231-17242. doi:10.1029/2000jd900014

Chen GX, Huang GH, Huang B, Wu J, Yu KW, Xu H, Xue XH (1995) $\mathrm{CH}_{4}$ and $\mathrm{N}_{2} \mathrm{O}$ emission from a rice field and effect of Azolla and fertilization on them. Chinese Journal of Applied Ecology 6:378 382. doi:10.13287/j.1001-9332.1995.0077 (in Chinese)

Chen GX, Huang GH, Huang B, Yu KW, Wu J, Xu H (1997) Nitrous oxide and methane emissions from soil-plant systems. Nutr Cycl Agroecosyst 49:41-45. doi:10.1023/A:1009758900629

Ciais P, Sabine C, Bala G, Bopp L, Brovkin V, Canadell J, Chhabra A, DeFries R, Galloway J, Heimann M, Jones C, Quéré CL, Myneni RB, Piao S, Thornton P (2013) Carbon and Other Biogeochemical Cycles. In: Stocker TF, Qin D, Plattner G-K, Tignor M, Allen SK, Boschung J, Nauels A, Xia Y, Bex V, Midgley PM (eds) Climate Change 2013: The Physical Science Basis Contribution of Working Group I to the Fifth Assessment Report of the Intergovernmental Panel on Climate Change. Cambridge University Press, Cambridge

Cissé M, Vlek PLG (2003a) Conservation of urea-N by immobilizationremobilization in a rice-Azolla intercrop. Plant Soil 250:95-104. doi: 10.1023/A:1022878306316

Cissé M, Vlek PLG (2003b) Influence of urea on biological $\mathrm{N}_{2}$ fixation and $\mathrm{N}$ transfer from Azolla intercropped with rice. Plant Soil 250: 105-112. doi:10.1023/A:1022830423154

Conrad R (2002) Control of microbial methane production in wetland rice fields. Nutr Cycl Agroecosyst 64:59-69. doi:10.1023/A: 1021178713988

FAO (2013) Food and Agriculture Organization statistical database. Agricultural data available @ http://faostat3.fao.org

Fosu-Mensah BY, Vlek PLG, Manske G, Mensah M (2015) The influence of Azolla pinnata on floodwater chemistry, grain yield and nitrogen uptake of Rice in Dano. Southwestern Burkina Faso J Agr Sci 7. doi:10.5539/jas.v7n8p118

Frolking S, Qiu J, Boles S, Xiao X, Liu J, Zhuang Y, Li C, Qin X (2002) Combining remote sensing and ground census data to develop new maps of the distribution of rice agriculture in China. Global Biogeochemical Cycles 16:38-31-38-10. doi:10.1029/ $2001 \mathrm{gb} 001425$

Hussain S, Peng S, Fahad S, Khaliq A, Huang J, Cui K, Nie L (2015) Rice management interventions to mitigate greenhouse gas emissions: a review. Environ Sci Pollut Res Int 22:3342-3360. doi:10.1007/ s11356-014-3760-4

Kollah B, Patra AK, Mohanty SR (2016) Aquatic microphylla Azolla: a perspective paradigm for sustainable agriculture, environment and global climate change. Environ Sci Pollut R 23:4358-4369. doi:10. 1007/s11356-015-5857-9

Kosten S, Pineiro M, de Goede E, de Klein J, Lamers LP, Ettwig K (2016) Fate of methane in aquatic systems dominated by free-floating plants. Water Res 104:200-207. doi:10.1016/j.watres.2016.07.054

Ma Y-Y, Tong C, Wang W-Q, Zeng C-S (2012) Effect of Azolla on $\mathrm{CH}_{4}$ and $\mathrm{N}_{2} \mathrm{O}$ emissions in Fuzhou Plain paddy fields. Chin J Eco-Agric 20:723-727. doi:10.3724/sp.j.1011.2012.00723 (in Chinese)

Malyan SK, Bhatia A, Kumar A, Gupta DK, Singh R, Kumar SS, Tomer R, Kumar O, Jain N (2016) Methane production, oxidation and mitigation: a mechanistic understanding and comprehensive evaluation of influencing factors. Sci Total Environ. doi:10.1016/j. scitotenv.2016.07.182

Montzka SA, Dlugokencky EJ, Butler JH (2011) Non- $\mathrm{CO}_{2}$ greenhouse gases and climate change. Nature 476:43-50. doi:10.1038/ nature 10322

Mosier AR, Halvorson AD, Reule CA, Liu XJ (2006) Net global warming potential and greenhouse gas intensity in irrigated cropping systems in northeastern Colorado. J Environ Qual 35: 1584-1598. doi:10.2134/jeq2005.0232

Myhre G, Shindell D, Bréon F-M, Collins W, Fuglestvedt J, Huang J, Koch D, Lamarque J-F, Lee D, Mendoza B, Nakajima T, Robock A, 
Stephens G, Takemura T, Zhang H (2013) Anthropogenic and natural radiative forcing. In: Stocker TF, Qin D, Plattner G-K, Tignor M, Allen SK, Boschung J, Nauels A, Xia Y, Bex V, Midgley PM (eds) Climate Change 2013: The Physical Science Basis Contribution of Working Group I to the Fifth Assessment Report of the Intergovernmental Panel on Climate Change. Cambridge University Press, Cambridge

Nguyen NV, Ferrero A (2006) Meeting the challenges of global rice production. Paddy \& Water Environment 4:1-9. doi:10.1007/ s10333-005-0031-5

Prasanna R, Kumar V, Kumar S, Yadav AK (2002) Methane production in rice soil is inhibited by cyanobacteria. Microbiol Res 157:1-6. doi:10.1078/0944-5013-00124

Shang QY, Yang XX, Gao CM, Wu PP, Liu JJ, Xu YC, Shen QR, Zou JW, Guo SW (2011) Net annual global warming potential and greenhouse gas intensity in Chinese double rice-cropping systems: a 3year field measurement in long-term fertilizer experiments. Glob Chang Biol 17:2196-2210. doi:10.1111/j.1365-2486.2010.02374.x

Vlek PLG, Diakite MY, Mueller H (1995) The role of Azolla in curbing ammonia volatilization from flooded rice systems. Nutr Cycl Agroecosyst 42:165-174. doi:10.1007/BF00750511

Wagner GM (1997) Azolla: a review of its biology and utilization. Bot Rev 63:1-26. doi:10.1007/Bf02857915
Wang C, Li S, Lai DYF, Wang W, Ma Y (2015) The effect of floating vegetation on $\mathrm{CH}_{4}$ and $\mathrm{N}_{2} \mathrm{O}$ emissions from subtropical paddy fields in China. Paddy Water Environ 13:425-431. doi:10.1007/s10333014-0459-6

Xie B, Zheng X, Zhou Z, Gu J, Zhu B, Chen X, Shi Y, Wang Y, Zhao Z, Liu C, Yao Z, Zhu J (2009) Effects of nitrogen fertilizer on $\mathrm{CH}_{4}$ emission from rice fields: multi-site field observations. Plant Soil 326:393-401. doi:10.1007/s11104-009-0020-3

Yao ZS, Zheng XH, Dong HB, Wang R, Mei BL, Zhu JG (2012) A 3-year record of $\mathrm{N}_{2} \mathrm{O}$ and $\mathrm{CH}_{4}$ emissions from a sandy loam paddy during rice seasons as affected by different nitrogen application rates. Agric Ecosyst Environ 152:1-9. doi:10.1016/j.agee.2012.02.004

Ying Z, Boeckx P, Chen GX, Cleemput OV (2000) Influence of Azolla on $\mathrm{CH}_{4}$ emission from rice fields. Nutr Cycl Agroecosyst 58:321-326. doi:10.1023/A:1009871308968

Zhang FS, Chen XP, Vitousek P (2013) Chinese agriculture: an experiment for the world. Nature 497:33-35. doi:10.1038/497033a

Zou JW, Huang Y, Jiang JY, Zheng XH, Sass RL (2005) A 3-year field measurement of methane and nitrous oxide emissions from rice paddies in China: effects of water regime, crop residue, and fertilizer application. Glob Biogeochem Cycles 19:9. doi:10.1029/ 2004gb002401 